Supporting information for

\title{
The first enantioenriched metalated nitrile possessing macroscopic configurational stability
}

Paul R. Carlier*, Yiqun Zhang

Department of chemistry, Virginia Tech, Blacksburg, VA 24061

pcarlier@vt.edu

\section{Table of Contents}

$\begin{array}{lll}\text { Section } & \text { Description } & \text { Page } \\ \text { A } & \text { Experimental procedures and Ortep of }(S)-(+)-5 \text { (Figure S1) } & \text { S1 } \\ \text { B. } & \text { Tabulation of HPLC conditions and retention times } & \text { S6 } \\ \text { C. } & \text { Overlay of }{ }^{1} \mathrm{H} \text { NMR Spectra of 5, 3, } d_{1}-\mathbf{3}, \mathbf{6 a} \text { (Figure S2) } & \text { S7 } \\ \text { D. } & { }^{1} \mathrm{H} \text { and }{ }^{13} \mathrm{C} \text { NMR Spectra, HPLC Chromatograms } & \text { S8 } \\ \text { E. } & \text { References } & \text { S23 }\end{array}$

\section{A. Experimental procedures:}

\section{General information:}

${ }^{1} \mathrm{H}$ NMR spectra were recorded on JEOL 500 and Varian $400 \mathrm{MHz}$ Spectrometers; the corresponding ${ }^{13} \mathrm{C}$ NMR resonant frequencies were 125 and $100 \mathrm{MHz}$ respectively. High resolution mass spectra were collected on a JEOL HX110 dual focusing mass spectrometer under FAB conditions (NBA, PEG). In conjunction with the ${ }^{1} \mathrm{H}$ and ${ }^{13} \mathrm{C}$ NMR spectra, the HRMS data confirm the proposed identity of each compound. Enantiomeric excess was assessed by chiral stationary phase HPLC (Chiralcel AD or OD). Tetrahydrofuran (THF) and diethyl ether were freshly distilled from sodium/benzophenone immediately before use. Dimethyl ether was condensed with a cold finger under nitrogen; reactions at $-135{ }^{\circ} \mathrm{C}$ were performed using a 3:2 diethyl ether/THF-LN2 cold bath. 1,1-Diphenylethylene, bromoform, $N$-hydroxysuccinimide (NHS), and EDCI were purchased from Aldrich without further purification unless otherwise noted. (-)-Brucine was purchased from Acros. (R)-(-)-3 $3^{1}$ and $( \pm)-4^{2}$ were prepared according to the literature methods. Organometallic reagents were purchased as 
follows: $n$-BuLi (2.5 M in hexane, Aldrich); $i$-PrMgBr (1.0 M in THF, TCI); $i$-PrMgCl (2.0 $\mathrm{M}$ in $\mathrm{Et}_{2} \mathrm{O}$, Aldrich); $\mathrm{EtMgBr}\left(3.0 \mathrm{M}\right.$ in $\mathrm{Et}_{2} \mathrm{O}$, Aldrich); $\mathrm{MeMgBr}\left(3.0 \mathrm{M}\right.$ in $\mathrm{Et}_{2} \mathrm{O}$, Aldrich); $t$ - $\mathrm{BuMgCl}$ (2.0 $\mathrm{M}$ in $\mathrm{Et}_{2} \mathrm{O}$, Aldrich); sec-BuLi (1.4 M in cyclohexane, Aldrich).

\section{(R)-(-)-1-deuterio-2,2-diphenyl-cyclopropylnitrile, $d_{1}-(R)-(-)-3$}

A solution of $\mathrm{NaOMe}$ in $\mathrm{CD}_{3} \mathrm{OD}(1 \mathrm{M}, 0.5 \mathrm{~mL})$ was added to $(R)-(-)-3(3.8 \mathrm{mg}, 0.017$ $\mathrm{mmol}$ ) and the mixture was heated with stirring at $50{ }^{\circ} \mathrm{C}$ under nitrogen. After 3 days, the reaction was quenched by the addition of saturated $\mathrm{NH}_{4} \mathrm{Cl}(1.0 \mathrm{~mL})$. Extractive workup, and concentration in vacuo gave $3.7 \mathrm{mg}$ of the titled compound ( $97 \%$ yield; $>99 \% d_{1}$ by $\left.{ }^{1} \mathrm{H} \mathrm{NMR}\right) .[\alpha]^{\mathrm{D}}=-310.7,(\mathrm{c}=0.08$, acetone); note that the reported rotation of $(R)-(-)-3$ is $-307^{\circ} .^{3}$ HPLC analysis (Chiralcel AD) indicated $>99 \%$ ee $(R)$.

${ }^{1} \mathrm{H}$ NMR $\left(\mathrm{CDCl}_{3}\right) \delta 1.80(\mathrm{~d}, J=5.2 \mathrm{~Hz}, 1 \mathrm{H}), 2.02(\mathrm{~d}, J=5.6 \mathrm{~Hz}, 1 \mathrm{H}), 7.17-7.53(\mathrm{~m}, 10 \mathrm{H})$;

${ }^{13} \mathrm{C} \mathrm{NMR}\left(\mathrm{CDCl}_{3}\right) \delta 12.1\left(t,{ }^{1} J_{\mathrm{C}-\mathrm{D}}=109 \mathrm{~Hz}\right), 21.0,38.3,119.6,127.49,127.87,128.03$, 128.58, 128.89, 128.95, 129.47, 129.90, 139.0, 142.4; HRMS (FAB) 221.1189 calcd for $\mathrm{C}_{16} \mathrm{H}_{13} \mathrm{DN},[\mathrm{M}+\mathrm{H}]^{+}$found $221.11850(-1.8 \mathrm{ppm},-0.4 \mathrm{mmu})$. The ${ }^{1} \mathrm{H}$ NMR chemical shifts of the enantioenriched $d_{1}-(R)-(-)-3$ were identical to that of the racemic $d_{1}-3$ reported by Walborsky. ${ }^{1}$

\section{(S)-(+)-1-bromo-2,2-diphenyl cyclopropylcarboxylic acid, $(S)-(+)-4$}

The resolution of $\mathbf{4}$ with brucine has been reported by Walborsky. ${ }^{4}$ Note that the this account does not provide any details, so we provide our procedure below. Furthermore, the 1961 paper's description of the quasiracemate method used to determine absolute configuration is marred by a typographical error regarding the absolute configuration of $(+)$-4. The correct $(S)$-absolute configuration of $(+)-\mathbf{4}$ is noted in two subsequent Walborsky publications. ${ }^{5,6}$

A mixture of ( \pm -4 (2.62 $\mathrm{g}, 8.25 \mathrm{mmol})$ and (-)-brucine $(3.25 \mathrm{~g}, 8.25 \mathrm{mmol})$ was dissolved in $70 \mathrm{~mL}$ acetone and $5 \mathrm{~mL}$ methanol. The solution was warmed at $60{ }^{\circ} \mathrm{C}$ for 
$30 \mathrm{~min}$, cooled to room temperature, and then placed in the refrigerator. The solid mass of crystals was collected, dryed, and recrystallized from $45 \mathrm{~mL}$ acetone and $6 \mathrm{~mL}$ methanol, affording the (-)-brucine salt of $(S)-(+)-4$ in $80 \%$ yield $\left(2.35 \mathrm{~g},[\alpha]^{\mathrm{D}}=+31.6^{\circ} \mathrm{c}\right.$ $=0.22$ in $\mathrm{EtOH})$. Since the rotation of this recystallized salt did not differ significantly from that of the first batch of crystals, 100\% enantiopurity was assumed. Salt break was performed by suspending the salt in water $/ \mathrm{CH}_{2} \mathrm{Cl}_{2}(10 \mathrm{~mL}$ each $)$ and addition of $37 \% \mathrm{HCl}$ until the aqueous phase reached $\mathrm{pH}$ 1. The two-phase mixture was extracted with $\mathrm{CH}_{2} \mathrm{Cl}_{2}(3 \times 15 \mathrm{~mL})$, the combined layers dried $\left(\mathrm{Na}_{2} \mathrm{SO}_{4}\right)$, filtered and concentrated in vacuo to afford $0.94 \mathrm{~g}(90 \%)$ of enantiomerically pure $(S)-(+)-4\left([\alpha]^{\mathrm{D}}=+83.4^{\circ}, \mathrm{c}=0.24\right.$ in EtOH), identical by ${ }^{1} \mathrm{H}$ NMR to the literature. ${ }^{4}$

${ }^{1} \mathrm{H}$ NMR $\left(\mathrm{CDCl}_{3}\right) \delta 2.07(\mathrm{~d}, J=6.4 \mathrm{~Hz}, 1 \mathrm{H}), 2.73(\mathrm{~d}, J=6.4 \mathrm{~Hz}, 1 \mathrm{H}), 7.16-7.47(\mathrm{~m}$, $10 \mathrm{H}) ;{ }^{13} \mathrm{C} \mathrm{NMR}\left(\mathrm{CDCl}_{3}\right) \delta 28.6,38.1,46.5,127.64,127.75,128.53,128.68,128.56$, 129.60, 140.3, 141.5, 173.9; HRMS (FAB) 317.017716 calcd for $\mathrm{C}_{16} \mathrm{H}_{14}{ }^{79} \mathrm{BrO}_{2},[\mathrm{M}+\mathrm{H}]^{+}$ found $317.02084(+9.8 \mathrm{ppm},+3.1 \mathrm{mmu})$

\section{$(S)-(+)-1-b r o m o-2,2-d i p h e n y l$ cyclopropylnitrile, $(S)-(+)-5$}

a)Preparation of $(S)-(+)$-1-bromo-2,2-diphenyl cyclopropylcarboxamide

To a mixture of $(S)-(+)-4(0.89 \mathrm{~g}, 2.8 \mathrm{mmol})$ and NHS $(0.48 \mathrm{~g}, 4.2 \mathrm{mmol})$ in $15 \mathrm{~mL}$ $\mathrm{CH}_{2} \mathrm{Cl}_{2}$ was added EDCI $(0.80 \mathrm{~g}, 4.2 \mathrm{mmol})$ in $15 \mathrm{~mL} \mathrm{CH}_{2} \mathrm{Cl}_{2}$ dropwise. After stirring for $6 \mathrm{~h}$, excess ammonium hydroxide $(20 \mathrm{~mL})$ was added and stirred overnight. After extractive work up and column chromatography (1:1, hexane:EtOAc), the pure amide was obtained in $84 \%$ yield $(0.73 \mathrm{~g})$. mp 147.6-148.4 ${ }^{\circ} \mathrm{C} .{ }^{1} \mathrm{H}$ NMR $\left(\mathrm{CDCl}_{3}\right) \delta 2.02(\mathrm{~d}, J=$ $6.0 \mathrm{~Hz}, 1 \mathrm{H}), 2.82(\mathrm{~d}, J=6.0 \mathrm{~Hz}, 1 \mathrm{H}), 5.64(\mathrm{br}, 1 \mathrm{H}), 6.81(\mathrm{br}, 1 \mathrm{H}), 7.13-7.45(\mathrm{~m}, 10 \mathrm{H})$;

${ }^{13} \mathrm{C} \mathrm{NMR}\left(\mathrm{CDCl}_{3}\right) \delta 27.4,45.8,127.14,127.30,128.24,128.40,128.54,129.37,140.3$, 142.1, 168.7; HRMS (FAB), 316.033700 calcd for $\mathrm{C}_{16} \mathrm{H}_{15}{ }^{79} \mathrm{BrON},[\mathrm{M}+\mathrm{H}]^{+}$found $316.0315(-7.0 \mathrm{ppm},-2.2 \mathrm{mmu})$. Note that the ${ }^{1} \mathrm{H}$ NMR spectral data of $(S)-(+)-5$ are consistent with that reported for the racemate. ${ }^{7}$ 
b)Dehydration of the amide to the nitrile.

A mixture of the amide $(0.22 \mathrm{~g}, 0.7 \mathrm{mmol})$ and $p$-TsCl $(0.42 \mathrm{~g}, 2.2 \mathrm{mmol})$ in $7 \mathrm{~mL}$ pyridine was stirred at $80{ }^{\circ} \mathrm{C}$ for 1 day. After extractive workup and column chromatography $(2: 1$, hexane:EtOAc) the titled nitrile was obtained in $66 \%$ yield $(0.14 \mathrm{~g})$, mp 134.4-135.7 ${ }^{\circ} \mathrm{C},[\alpha]^{\mathrm{D}}=+8.1^{\circ}, \mathrm{c}=0.16$ in EtOH. HPLC indicated $>95 \%$ ee (no sign of the other enantiomer, but baseline separation of the enantiomers of the racemate could not be achieved). Note that the ${ }^{1} \mathrm{H}$ NMR spectral data of (S)-(+)-5 are consistent with that reported for the racemate. ${ }^{7}$

${ }^{1} \mathrm{H}$ NMR $\left(\mathrm{CDCl}_{3}\right) \delta 2.21(\mathrm{~d}, J=6.8 \mathrm{~Hz}, 1 \mathrm{H}), 2.53(\mathrm{~d}, J=6.8 \mathrm{~Hz}, 1 \mathrm{H}), 7.23-7.51(\mathrm{~m}$, $10 \mathrm{H}) ;{ }^{13} \mathrm{C} \mathrm{NMR}\left(\mathrm{CDCl}_{3}\right) \delta 18.7,30.0,44.6,118.3,128.09,128.27,128.65,128.72$, 129.07, 129.26, 138.83, 139.14; HRMS (FAB) 298.023135 calcd $\mathrm{C}_{16} \mathrm{H}_{12}{ }^{79} \mathrm{BrN},[\mathrm{M}+\mathrm{H}]^{+}$ found $298.02057(-8.5 \mathrm{ppm},-2.5 \mathrm{mmu})$.

X-ray crystallography confirmed (S)-configuration (Figure S1).

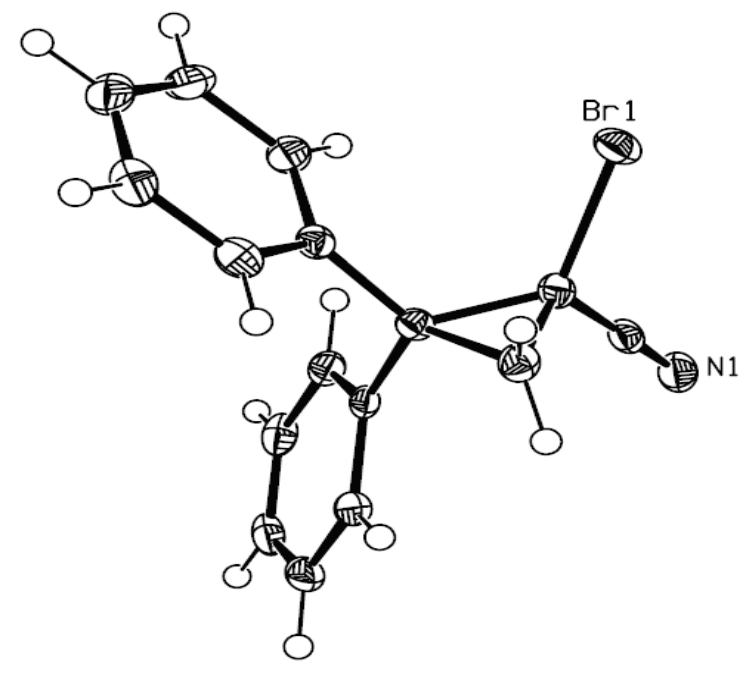

Figure S1. Ortep view of $(S)-(+)-5,50 \%$ ellipsoid possibility. 
General in situ protocol for the in situ metal-bromine exchange/methylation of (S)-(+)-5.

At $-100{ }^{\circ} \mathrm{C}\left(\mathrm{Et}_{2} \mathrm{O} / \mathrm{CO}_{2}\right.$ bath $)$ under nitrogen, to a stirred solution of $(S)-(+)-5(0.025 \mathrm{mmol})$ and the electrophile $\left(0.15 \mathrm{mmol}, \mathrm{CH}_{3} \mathrm{I}\right.$ or $\left.\mathrm{CD}_{3} \mathrm{I}\right)$ in anhydrous $\mathrm{Et}_{2} \mathrm{O}(1.0 \mathrm{~mL})$ was added the base $(0.026 \mathrm{mmol})$ and the mixture was stirred for $1 \mathrm{~h}$. The reaction was quenched by addition of saturated aqueous $\mathrm{NH}_{4} \mathrm{Cl}$ or $\mathrm{D}_{2} \mathrm{O}$ at $-100{ }^{\circ} \mathrm{C}$, and extracted with $\mathrm{Et}_{2} \mathrm{O}(3$ x 5 $\mathrm{mL}$ ). The combined extracts were dried over anhydrous $\mathrm{Na}_{2} \mathrm{SO}_{4}$, filtered, and concentrated. The crude product was analyzed by ${ }^{1} \mathrm{H}$ NMR and the product distributions are listed in Table 1 . These ${ }^{1} \mathrm{H}$ NMR spectra were very clean; no unidentified materials were present in any significant amount. For reference, an overlay of the ${ }^{1} \mathrm{H}$ NMR spectra of purified samples $\mathbf{5}, \mathbf{3}, d_{1} \mathbf{- 3}$, and $\mathbf{6 a}$ is given in Figure S2. Subsequently, preparative TLC $\left(50 / 50 \mathrm{CH}_{2} \mathrm{Cl}_{2} /\right.$ hexane) was performed to isolate $\mathbf{5}$ from $\mathbf{3} / d_{1}-\mathbf{3} / \mathbf{6 a}, \mathbf{b}$; note that $\mathbf{3} / d_{1}-\mathbf{3}$ and $\mathbf{6 a}, \mathbf{b}$ are coincident by TLC. Total mass balance following chromatography ranged from $60-75 \%$. The enantiomeric excess of 5 was determined by chiral stationary phase HPLC with a Chiracel OD column. The fraction containing 3/ $/ d_{1}-\mathbf{3}$ and 6a,b was analyzed by HPLC twice: once on Chiralcel AD to determine the enantiomeric excess of $\mathbf{3} / d_{1}-\mathbf{3}$, and once on Chiralcel AD to determine the enantiomeric excess of $\mathbf{6 a}, \mathbf{b}$. Note that the peak area ratios of $\mathbf{3} / d_{1}-\mathbf{3}$ to $\mathbf{6 a}, \mathbf{b}$ obtained by HPLC are consistent with the ratios measured by ${ }^{1} \mathrm{H}$ NMR in the crude product (assuming identical molar extinction coefficients of these chemically similar compounds).

\section{1-methyl-2,2-diphenyl-cyclopropylnitrile, 6 a}

Spectral data are consistent with that reported by Walborsky. ${ }^{3}$

${ }^{1} \mathrm{H} \mathrm{NMR}\left(\mathrm{CDCl}_{3}\right) \delta 1.29(\mathrm{~s}, 3 \mathrm{H}), 1.64(\mathrm{~d}, J=5.6 \mathrm{~Hz}, 1 \mathrm{H}), 2.05(\mathrm{~d}, J=5.2 \mathrm{~Hz}, 1 \mathrm{H})$, 7.17-7.53 (m, 10H); ${ }^{13} \mathrm{C} \mathrm{NMR}\left(\mathrm{CDCl}_{3}\right) \delta 16.7,19.9,26.4,42.9,122.7,127.54,127.67$, 128.56, 128.85, 128.91, 129.21, 129.39, 139.5, 141.6; HRMS (FAB) 234.128274 calcd for $\mathrm{C}_{17} \mathrm{H}_{16} \mathrm{~N},[\mathrm{M}+\mathrm{H}]^{+}$found $234.12860(+1.4 \mathrm{ppm},+0.3 \mathrm{mmu})$. 
1-trideuteriomethyl-2,2-diphenyl-cyclopropylnitrile, $6 \mathrm{~b}$

${ }^{1} \mathrm{H}$ NMR $\left(\mathrm{CDCl}_{3}\right) \delta 1.63(\mathrm{~d}, J=5.2 \mathrm{~Hz}, 1 \mathrm{H}), 2.04(\mathrm{~d}, J=5.6 \mathrm{~Hz}, 1 \mathrm{H}), 7.17-7.51(\mathrm{~m}$, $10 \mathrm{H}) ;{ }^{13} \mathrm{C} \mathrm{NMR}\left(\mathrm{CDCl}_{3}\right) \delta 16.6,26.5,43.0,122.9,127.69,127.83,129.00,129.06$, 129.37, 129.53, 139.6, 141.7. HRMS (FAB) 237.1471 calculated for $\mathrm{C}_{17} \mathrm{H}_{13} \mathrm{D}_{3} \mathrm{~N}$ $\left[\mathrm{M}+\mathrm{H}^{+}\right]$; found $237.1451(+8.4 \mathrm{ppm},+2.0 \mathrm{mmu})$.

General protocol for sequential magnesium-bromine exchange/deuteration of (S)-(+)-5.

At the indicated temperature under nitrogen, to a stirred solution of $(S)-(+)-5(0.025$ $\mathrm{mmol})$ in anhydrous $\mathrm{Et}_{2} \mathrm{O}(1.0 \mathrm{~mL})$ the $i-\mathrm{PrMgCl}\left(2.0 \mathrm{M}\right.$ in $\left.\mathrm{Et}_{2} \mathrm{O}, 0.055 \mathrm{mmol}, 28 \mathrm{uL}\right)$, was added and the mixture was stirred for $1 \mathrm{~min}, 5 \mathrm{~min}$, or $30 \mathrm{~min}$. The reaction was quenched by $\mathrm{D}_{2} \mathrm{O}$, and extracted with $\mathrm{Et}_{2} \mathrm{O}(3 \times 5 \mathrm{~mL})$. The combined extracts were dried over anhydrous $\mathrm{Na}_{2} \mathrm{SO}_{4}$, filtered, and concentrated, and analyzed as described above for the in situ reactions of $\mathbf{5}$. The results are given in Table 2 of the paper. Mass balance following chromatography in these experiments ranged from 53-58\%.

\section{B. Tabulation of HPLC conditions and retention times for cyclopropylnitriles.}

Reported retention times are determined from racemic and enantiomerically enriched samples on Chiralcel AD or OD column.

\begin{tabular}{ccccc}
\hline sample & column & solvent, flowrate & $\begin{array}{c}\text { fast enantiomer } \\
\text { retention time } \\
\text { (config.) }\end{array}$ & $\begin{array}{c}\text { Slow enantiomer } \\
\text { retention time } \\
\text { (config.) }\end{array}$ \\
\hline$( \pm)-3$ & AD & $\begin{array}{c}1 \% \text { isopropanol- } \\
\text { hexane, } 0.8 \mathrm{~mL} / \mathrm{min} \\
1 \% \text { isopropanol- }\end{array}$ & $28.1 \mathrm{~min}(\mathrm{R})$ & $29.2 \mathrm{~min}(\mathrm{~S})$ \\
$( \pm)-5$ & OD & $\begin{array}{c}1 \% \text { min }(\mathrm{S}) \\
\text { hexane, } 0.8 \mathrm{~mL} / \mathrm{min} \\
6 \% \text { isopropanol- } \\
\text { hexane, } 0.5 \mathrm{~mL} / \mathrm{min}\end{array}$ & $19.5 \mathrm{~min}$ & $20.6 \mathrm{~min}$ \\
\hline
\end{tabular}




\section{C. ${ }^{1} \mathrm{H}$ NMR chemical shifts of cyclopropyl ring protons}
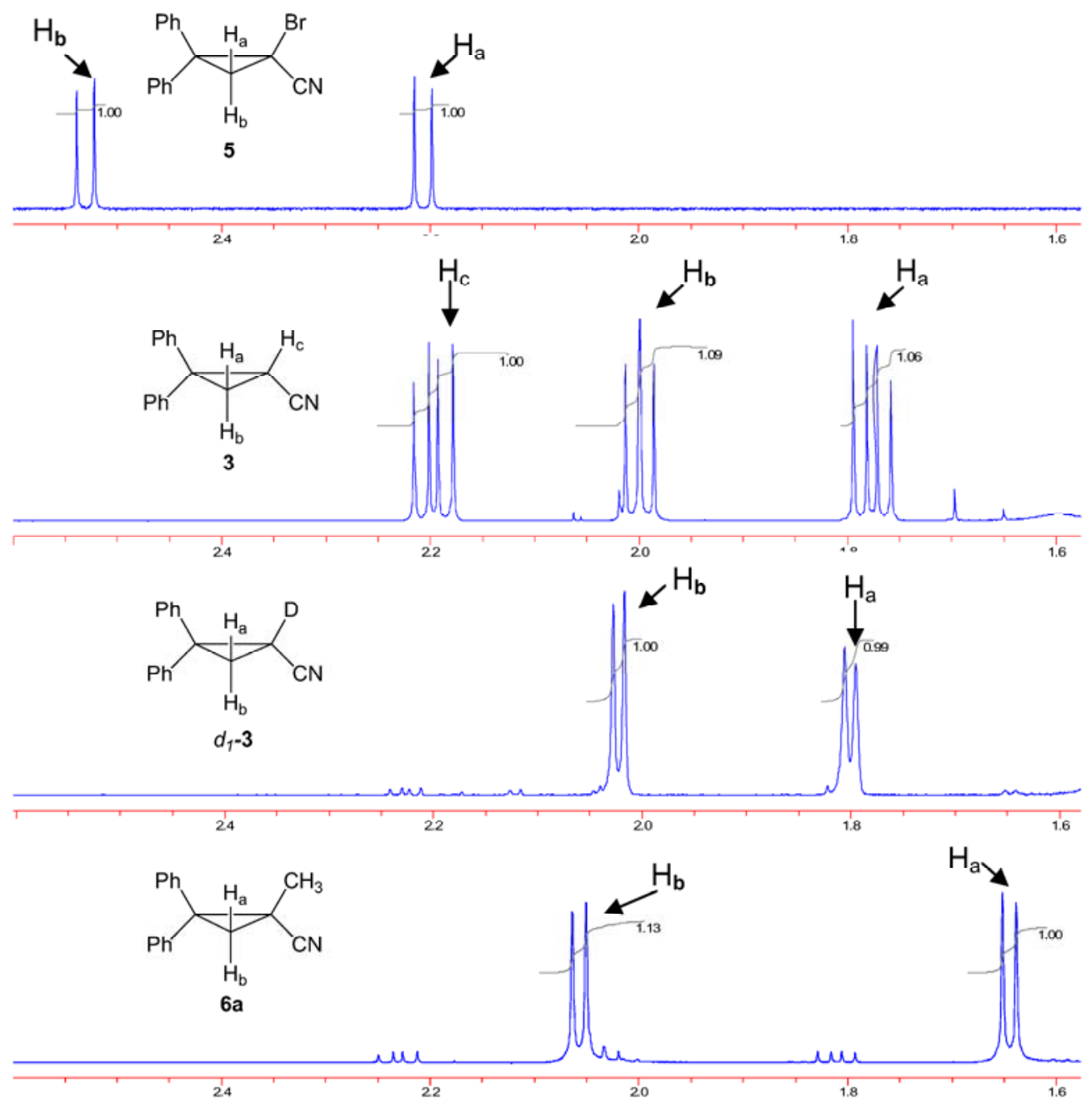

Figure S2 ${ }^{1} \mathrm{H}$ NMR $\left(\mathrm{CDCl}_{3}\right)$ chemical shifts of cyclopropyl ring protons of $\mathbf{5}, \mathbf{3}, d_{1}-\mathbf{3}$, and 6a. Note that the spectrum of $d_{1}-\mathbf{3}$ contains a small amount of $\mathbf{3}$. Likewise, the spectrum of 6a indicates the presence of a small amount of $\mathbf{3}$ (chromatographically inseparable).

\section{D. ${ }^{1} \mathrm{H}$ and ${ }^{13}$ NMR spectra, HPLC chromatograms (see following pages)}




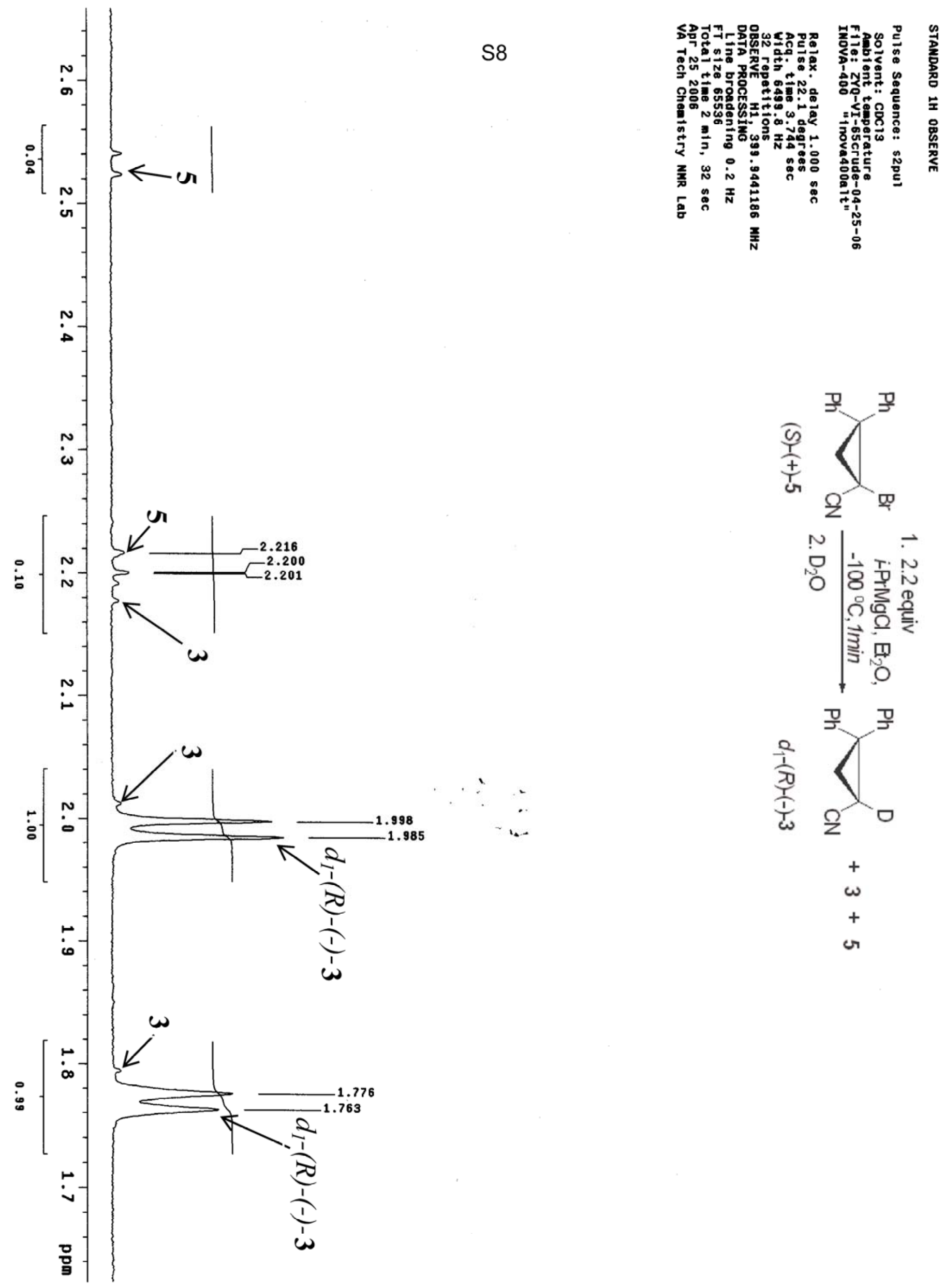




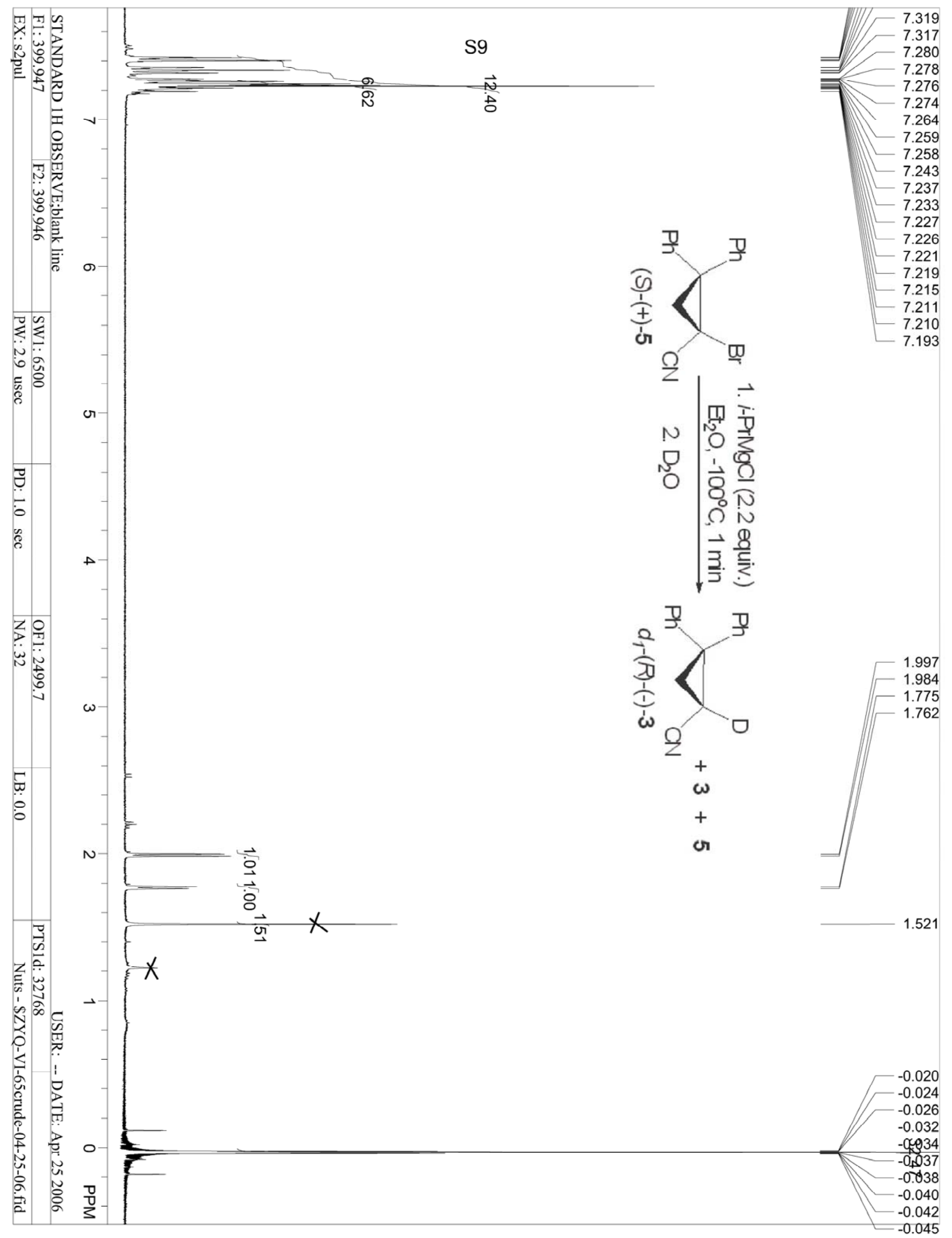




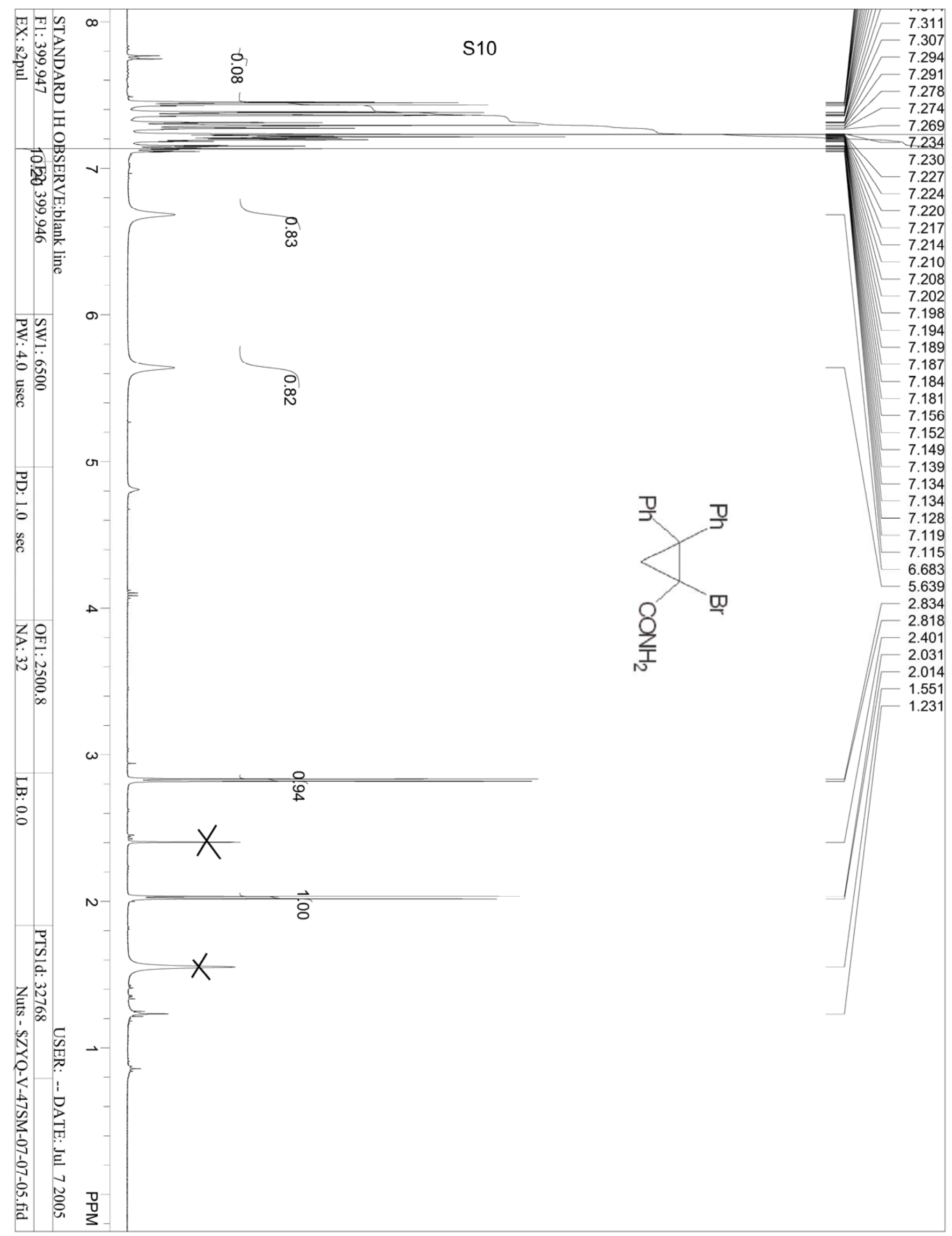




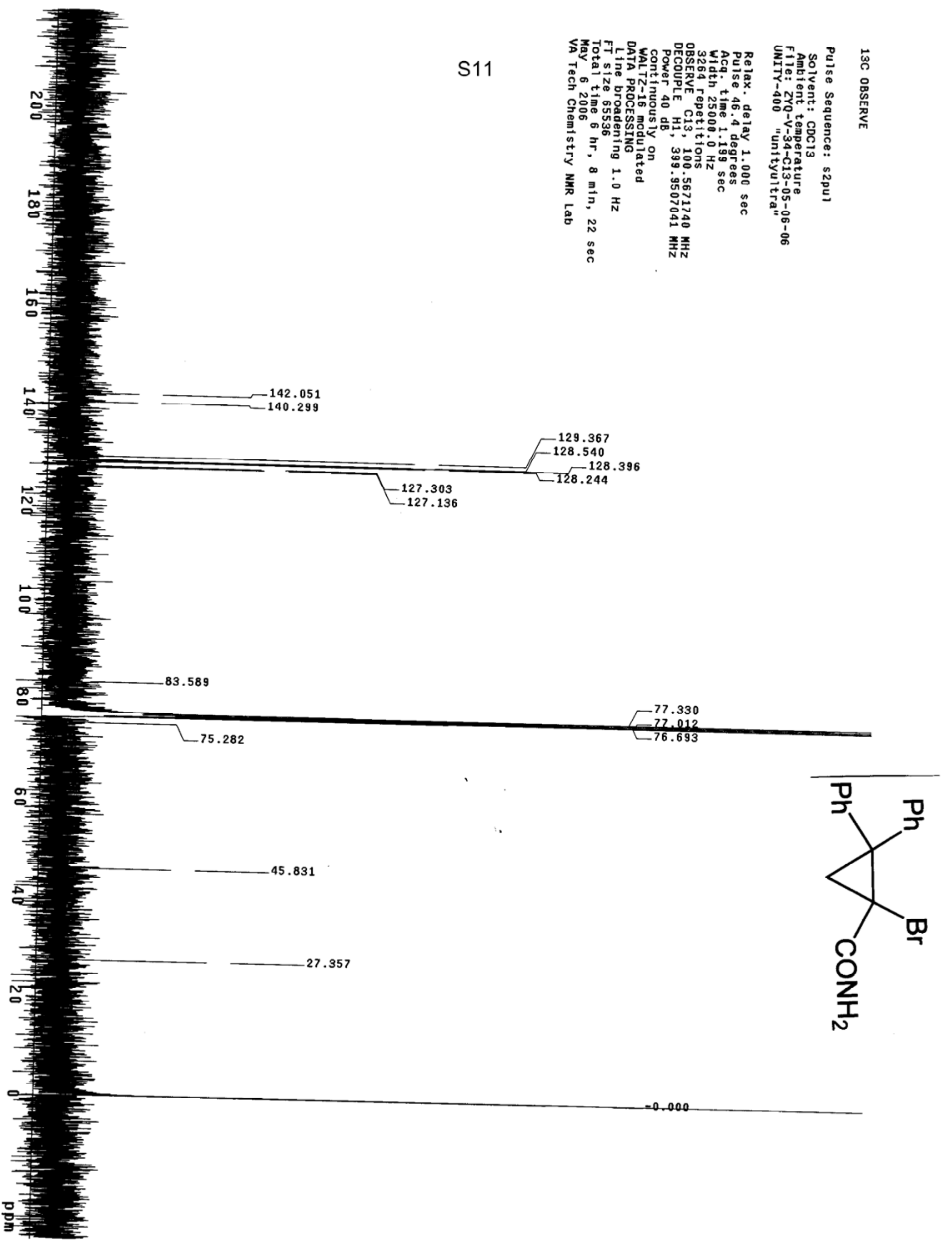




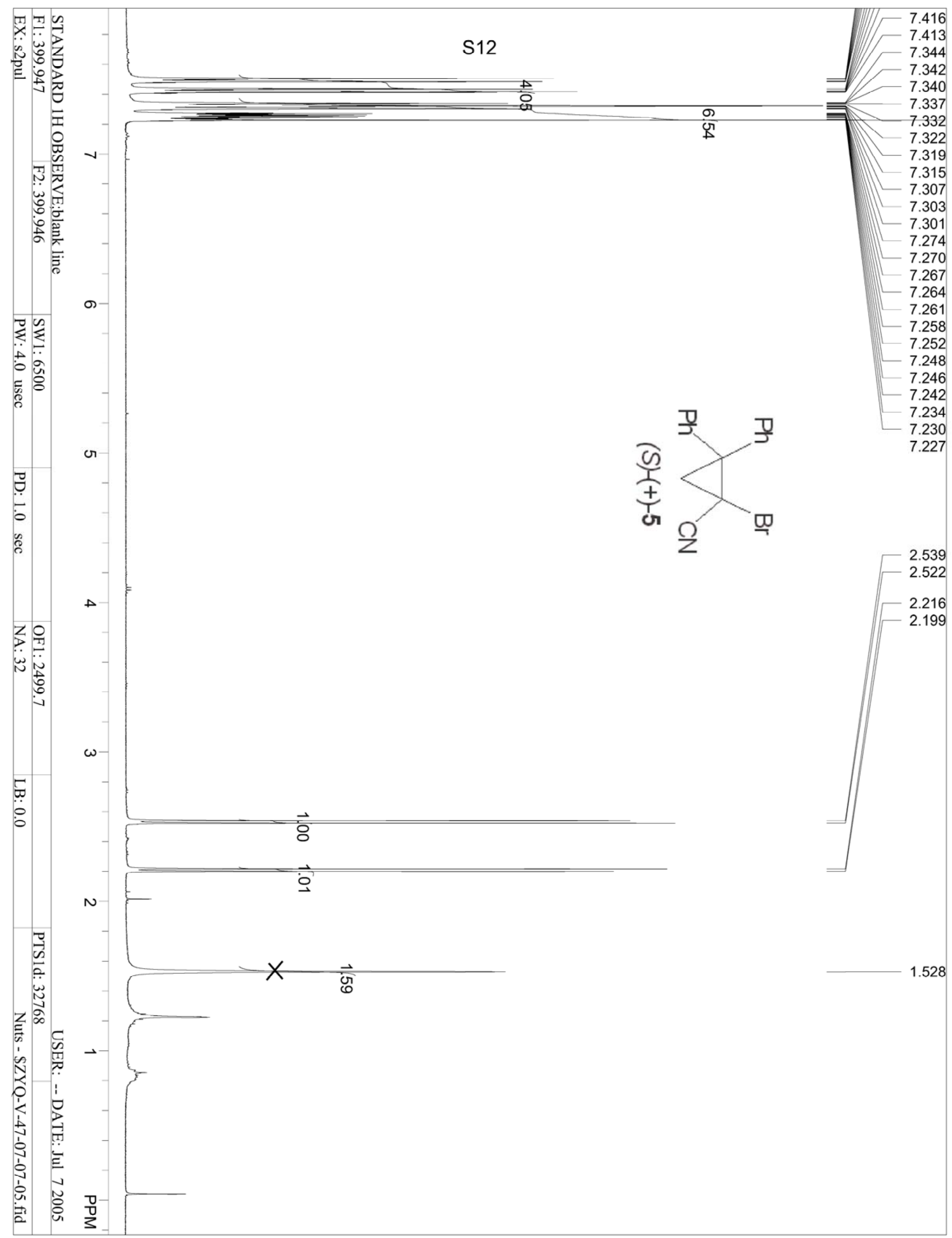




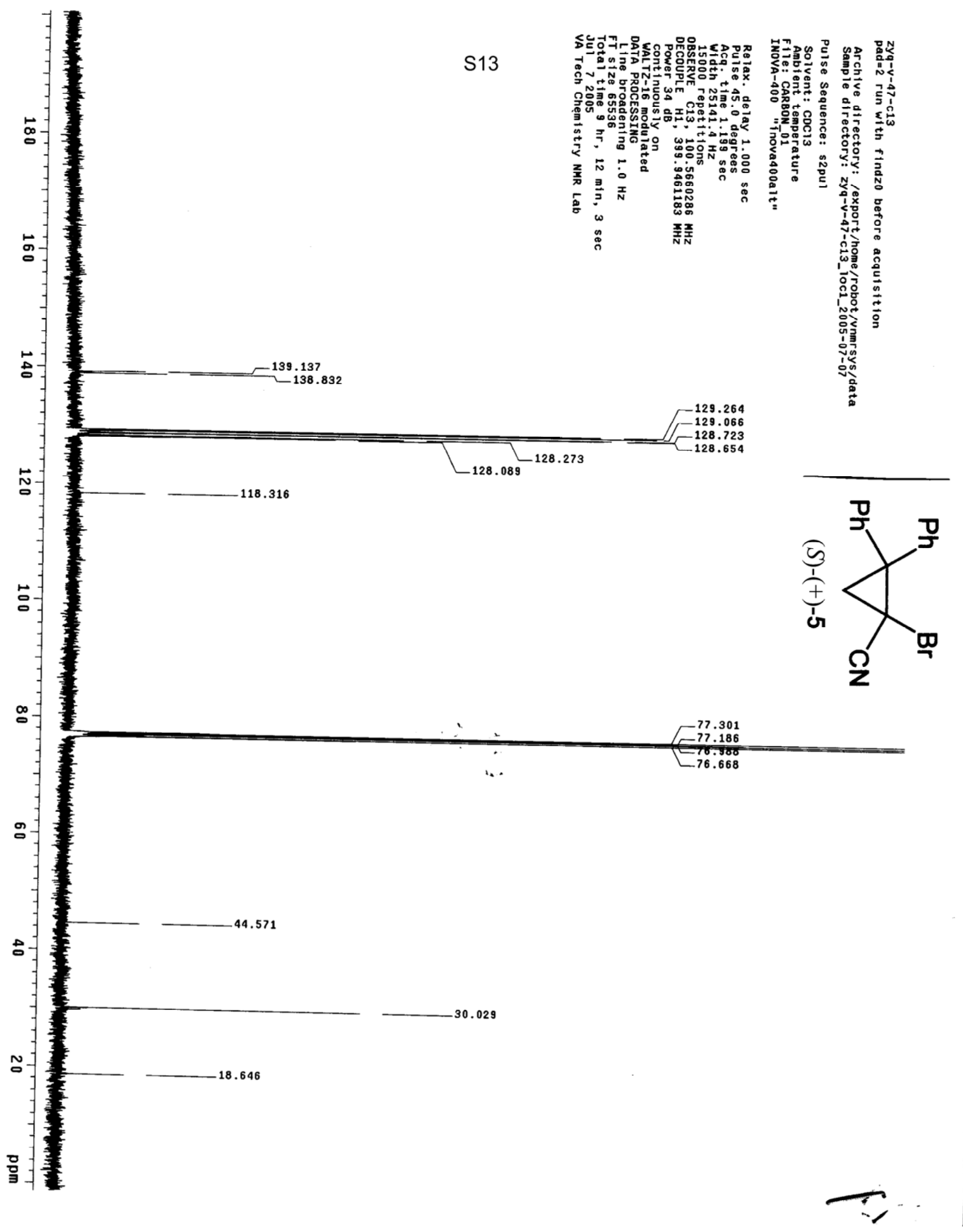




\begin{tabular}{|llll|}
\hline & \multicolumn{2}{c|}{ S A M P L E } & I N F O R M A T I O N \\
\hline \hline Sample Name: & ZYQ-V-36a-OD-03-16-06 & Acquired By: & Yiqun \\
Sample Type: & Unknown & Date Acquired: & 3/16/06 5:52:15 AM \\
Vial: & 1 & Acq. Method: & $1 \%$ B 80\%flow \\
Injection \#: & 1 & Date Processed: & $3 / 16 / 06$ 6:48:58 AM \\
Injection Volume: & 10.00 ul & Channel Name: & 2487Channel 1 \\
Run Time: & 40.00 Minutes & Sample Set Name & ZYQ_03_16_06 \\
Column Type: & OD & & \\
& & & \\
\hline
\end{tabular}

Detector Noise:

Detector Drift:

Peak to Peak Nois
Average Detector Noise:

Average Detector Drift:

Average Peak to Peak Noise

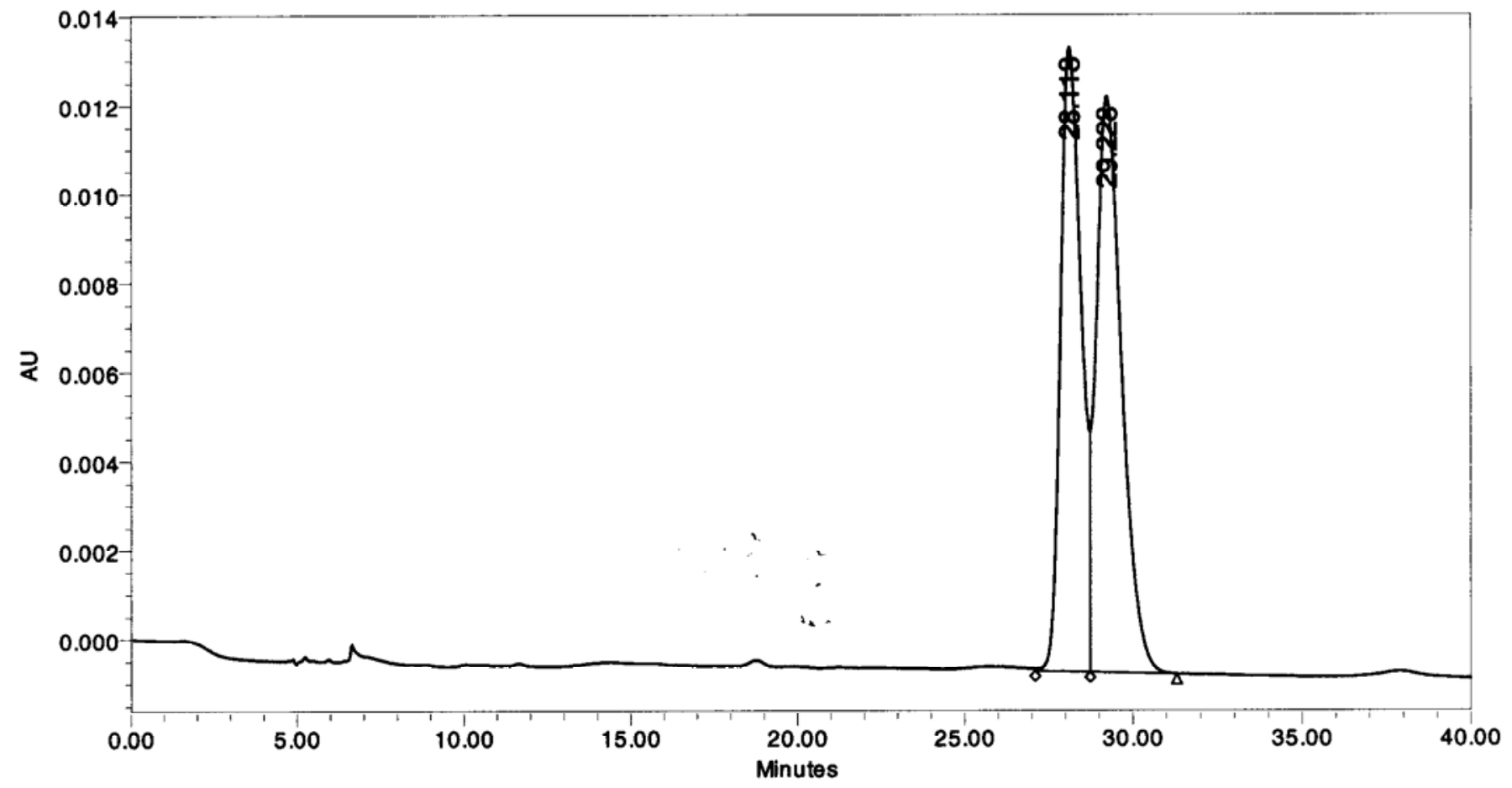

\begin{tabular}{|c|c|r|r|r|r|}
\hline & $\begin{array}{c}\mathrm{RT} \\
(\mathrm{min})\end{array}$ & $\begin{array}{c}\text { Area } \\
\left(\mu \mathrm{V}^{*} \mathrm{sec}\right)\end{array}$ & $\%$ Area & $\begin{array}{c}\text { Height } \\
(\mu \mathrm{V})\end{array}$ & $\%$ Height \\
\hline 1 & 28.118 & 603455 & 46.98 & 14048 & 52.01 \\
\hline 2 & 29.228 & 681018 & 53.02 & 12964 & 47.99 \\
\hline
\end{tabular}

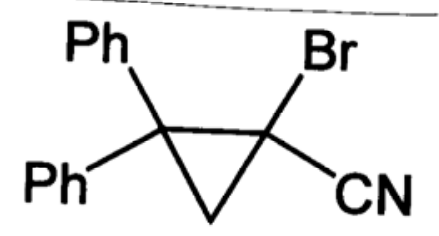

$( \pm)-5$ 


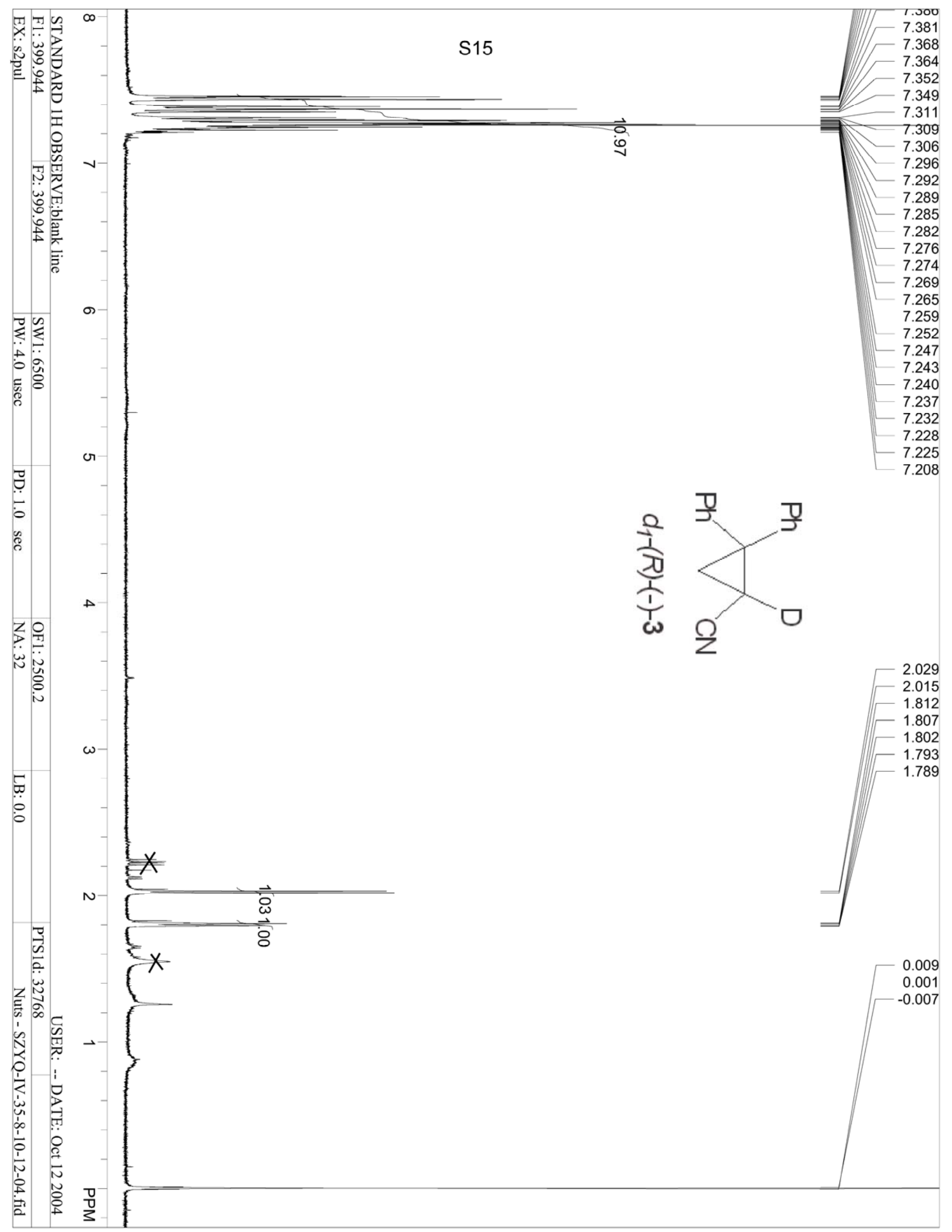



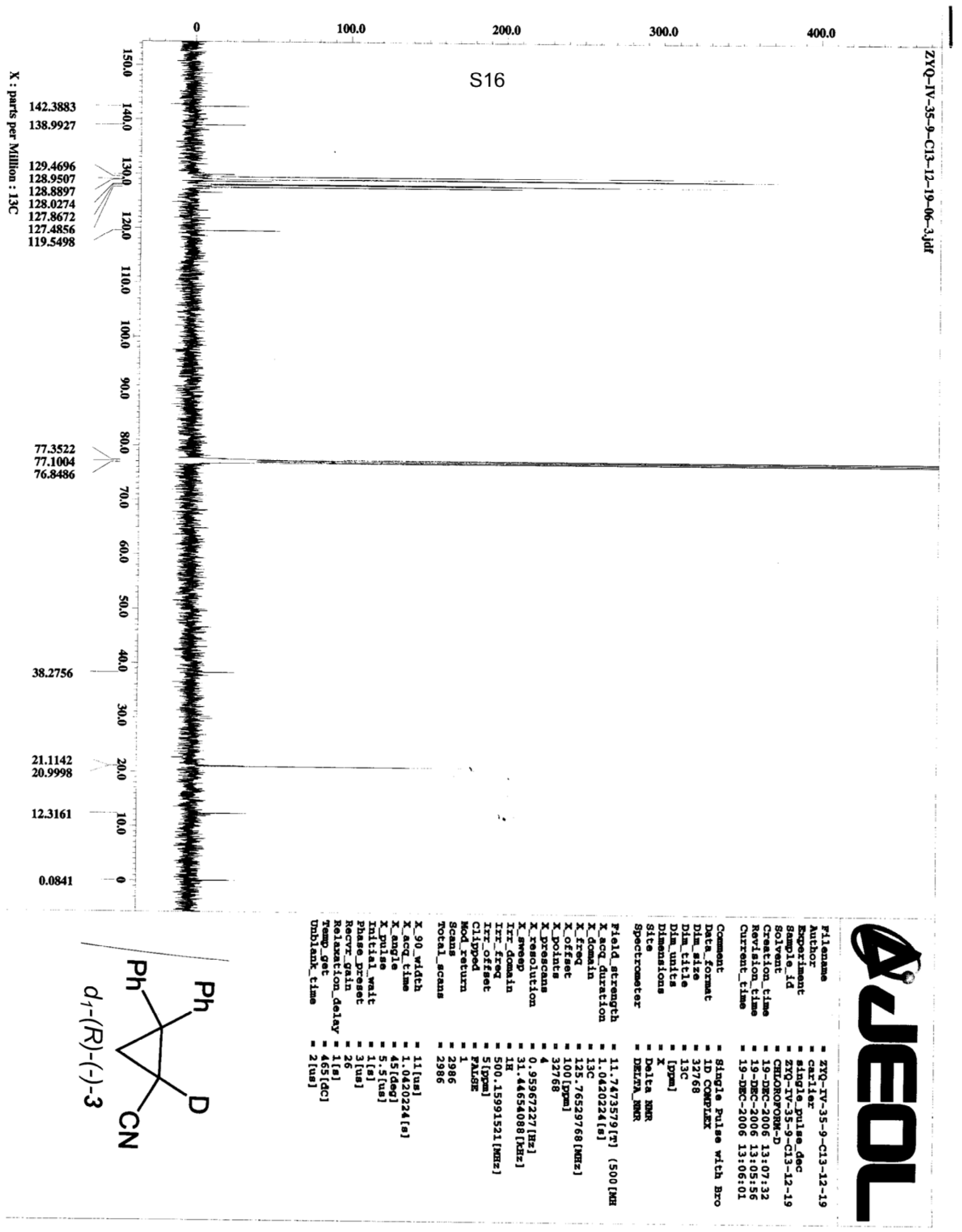


\section{VA TECH}

Project Name: Yiqun

Reported by User: Yiqun

\section{SAMPLE INFORMATION}

Sample Name: $\quad$ ZYQ-VI-27-H/D-AD-11-29-06

Sample Type: Unknown

Vial: $\quad 4$

Injection \#: $\quad 1$

Injection Volume: $10.00 \mathrm{ul}$

Run Time: $\quad 30.00$ Minutes

Column Type: $\quad$ AD
Acquired By: Yiqun

Date Acquired: $\quad$ 11/29/06 7:11:01 AM

Acq. Method: $\quad 1 \% B @ 80 \%$ flow

Date Processed: $11 / 29 / 06$ 8:00:41 AM

Channel Name: 2487Channel 1

Sample Set Nam ZYQ_11_29_06
Detector Noise:

Detector Drift:

Peak to Peak Nois
Average Detector Noise:

Average Detector Drift:

$\therefore$ Average Peak to Peak Nois

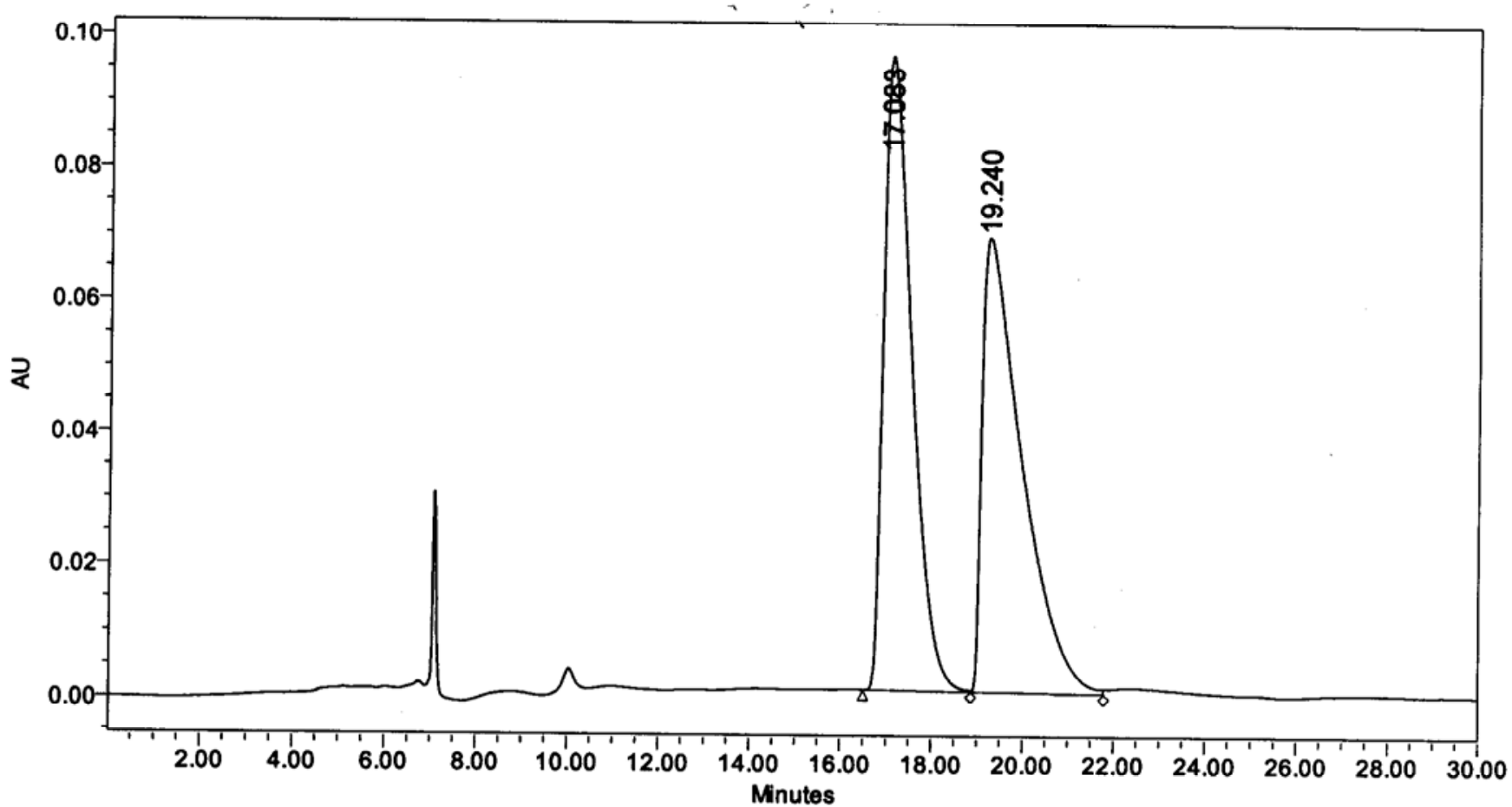

\begin{tabular}{|c|c|c|r|r|r|}
\hline & $\begin{array}{c}\mathrm{RT} \\
(\mathrm{min})\end{array}$ & $\begin{array}{c}\text { Area } \\
(\mu \mathrm{V} \text { *sec })\end{array}$ & $\%$ Area & $\begin{array}{c}\text { Height } \\
(\mu \mathrm{V})\end{array}$ & $\%$ Height \\
\hline 1 & 17.083 & 4133320 & 49.78 & 95795 & 58.25 \\
\hline 2 & 19.240 & 4170489 & 50.22 & 68648 & 41.75 \\
\hline
\end{tabular}

$0 \%$

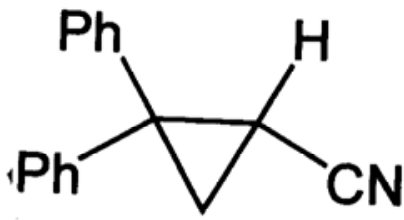

(士) 3 


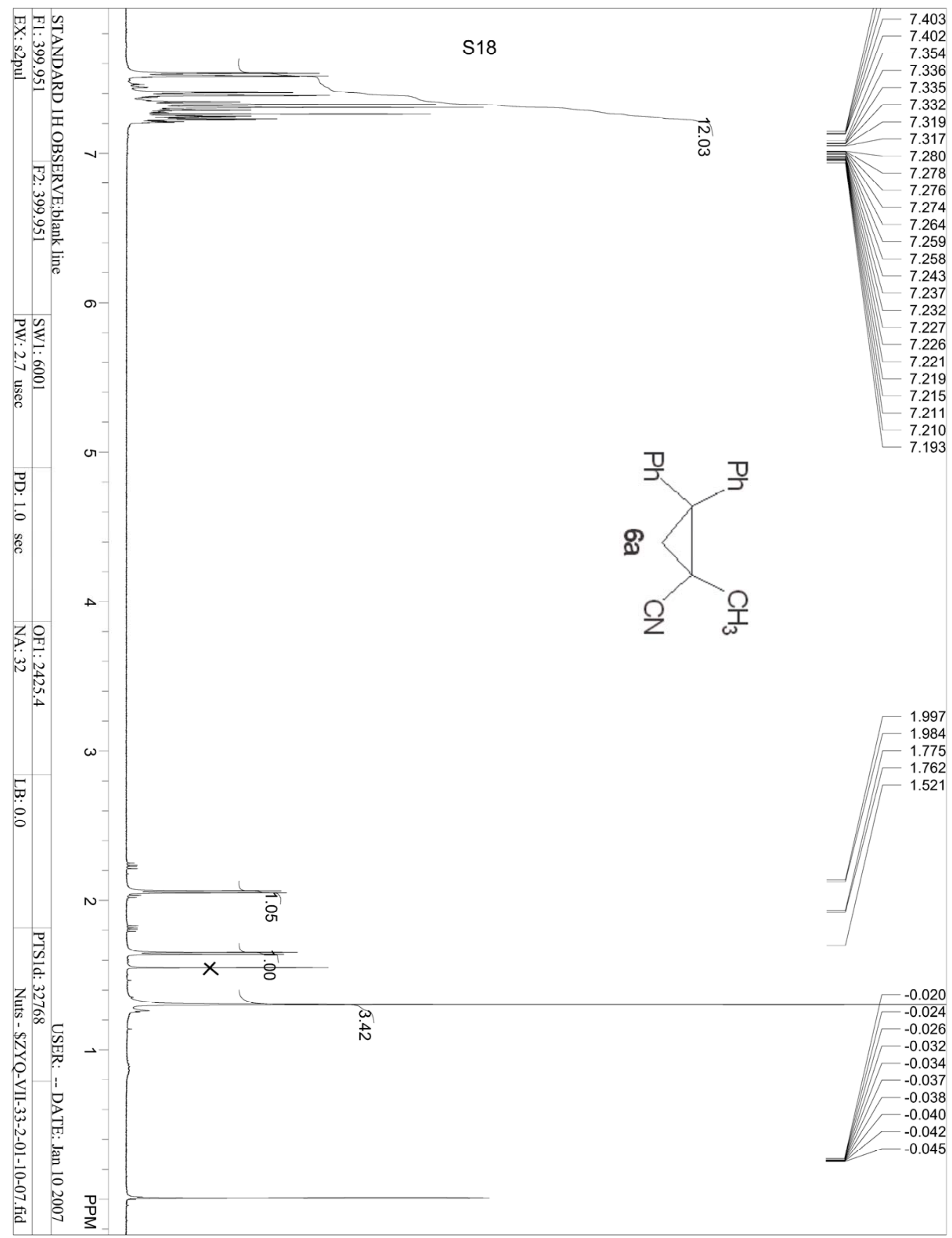




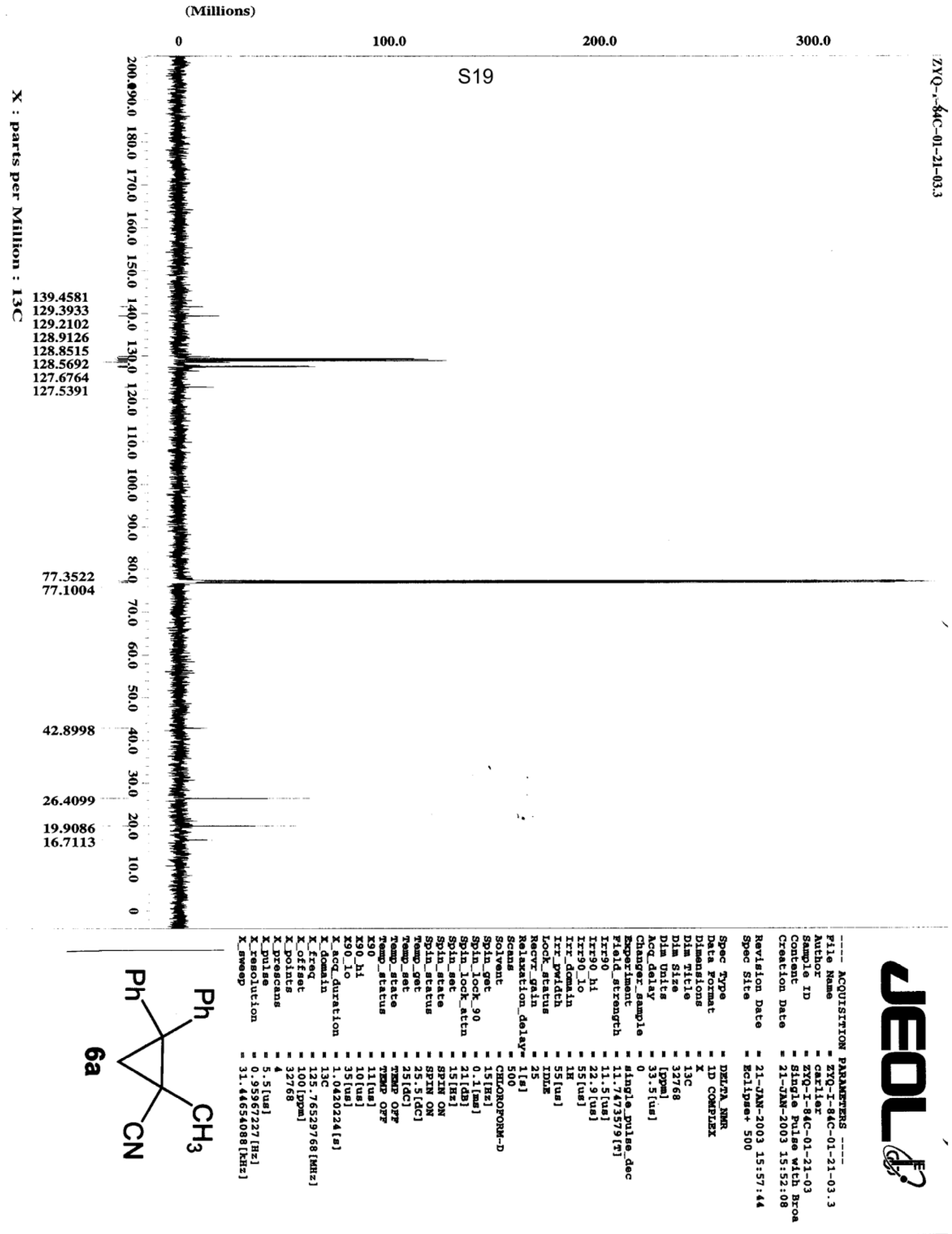


VA TECH

Project Name: Yiqun

Reported by User: Yiqun

\section{SAMPLE INFORMATION}

$\begin{array}{ll}\text { Sample Name: } & \text { ZYQ-184-OD-07-25-06 } \\ \text { Sample Type: } & \text { Unknown } \\ \text { Vial: } & 1 \\ \text { Injection \#: } & 1 \\ \text { Injection Volume: } & 10.00 \mathrm{ul} \\ \text { Run Time: } & 30.00 \text { Minutes } \\ \text { Column Type: } & \text { OD }\end{array}$

Detector Noise:

Detector Drift:

Peak to Peak Nois
Acquired By: Yiqun

Date Acquired: $\quad 7 / 25 / 066: 21: 54 \mathrm{AM}$

Acq. Method: $\quad 6 \% \mathrm{~B} @ 50 \%$ flow

Date Processed: $7 / 25 / 06$ 8:20:44 AM

Channel Name: 2487 Channel 1

Sample Set Nam ZYQ_07_25_06

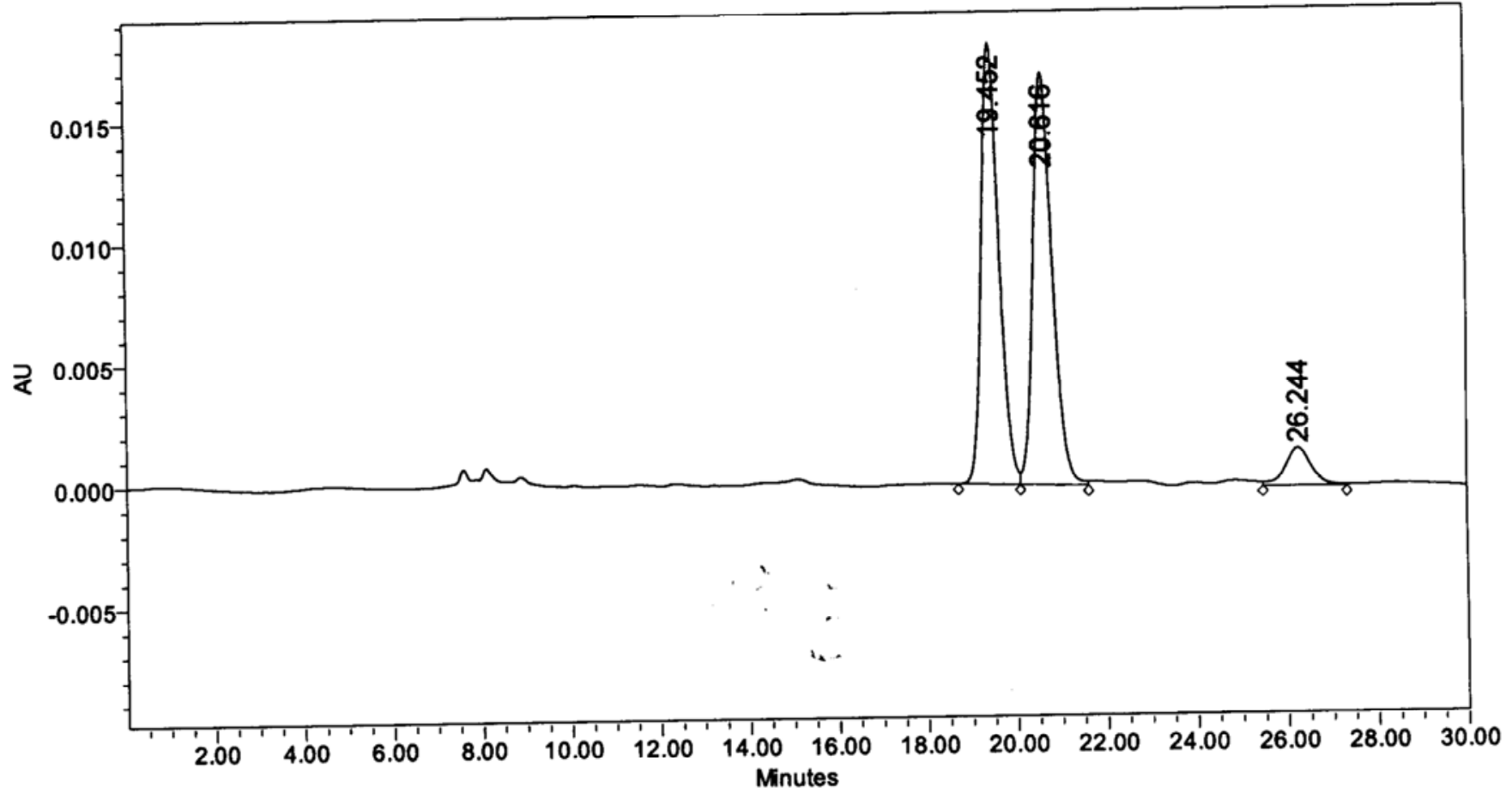

\begin{tabular}{|l|c|r|r|r|r|}
\hline & $\begin{array}{c}\mathrm{RT} \\
(\mathrm{min})\end{array}$ & $\begin{array}{c}\text { Area } \\
\left(\mu \mathrm{V}^{*} \mathrm{sec}\right)\end{array}$ & $\%$ Area & $\begin{array}{c}\text { Height } \\
(\mu \mathrm{V})\end{array}$ & $\%$ Height \\
\hline 1 & 19.452 & 498419 & 46.64 & 18171 & 49.52 \\
\hline 2 & 20.616 & 507576 & 47.50 & 16970 & 46.24 \\
\hline 3 & 26.244 & 62589 & 5.86 & 1555 & 4.24 \\
\hline
\end{tabular}

Average Detector Noise:

Average Detector Drift:

Average Peak to Peak Nois 


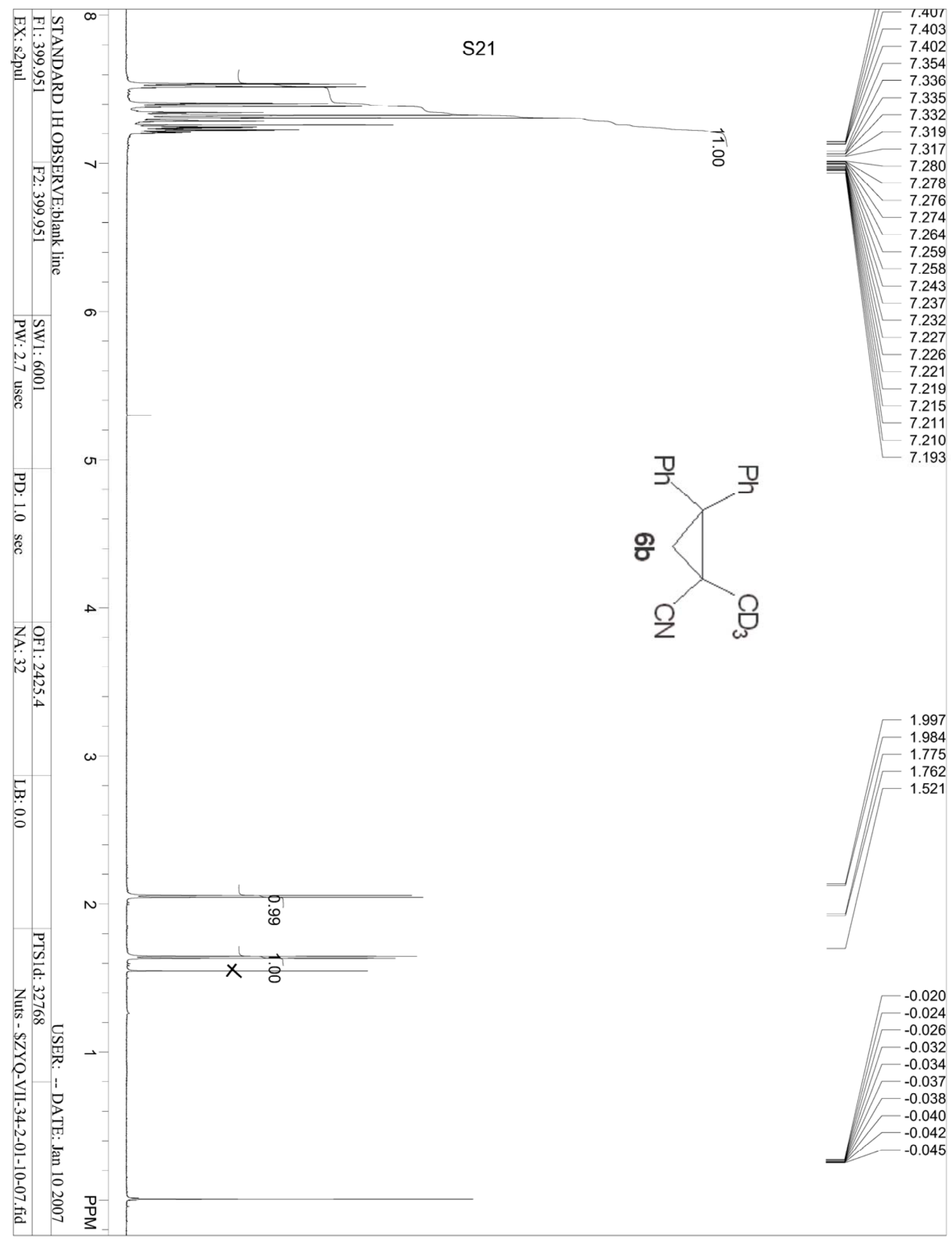




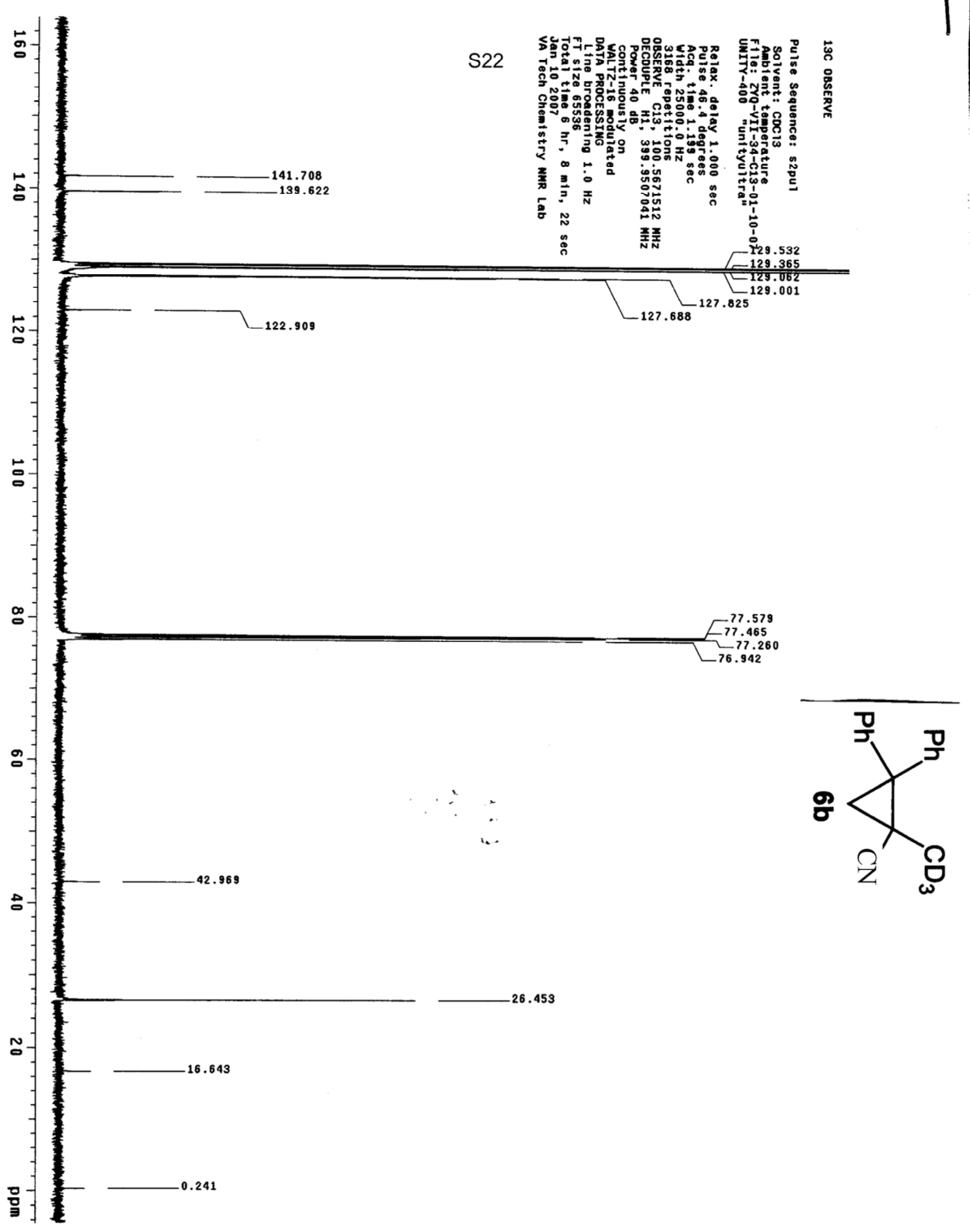




\section{E. References}

(1) Walborsky, H. M.; Motes, J. M. J. Am. Chem. Soc. 1970, 92, 2445-2450.

(2) Baird, M. S.; Nizovtsev, A. V.; Bolesov, I. G. Tetrahedron 2002, 58, 1581-1593.

(3) Walborsky, H. M.; Hornyak, F. M. J. Am. Chem. Soc. 1955, 77, 6026-6029.

(4) Walborsky, H. M.; Barash, L.; Young, A. E.; Impastato, F. J. J. Am. Chem. Soc. 1961, 83, 2517-2525.

(5) Walborsky, H. M.; Impastato, F. J.; Young, A. E. J. Am. Chem. Soc. 1964, 86, 3283-3288.

(6) Gawroński, J.; Gawrońska, K.; Radocki, D.; Walborsky, H. M. Tetrahedron: Asymmetry 1993, 4, 383-392.

(7) Dembkowski, L.; Rachon, J. Phos. Sulf. Sil. Rel. El. 1994, 91, 251-262. 